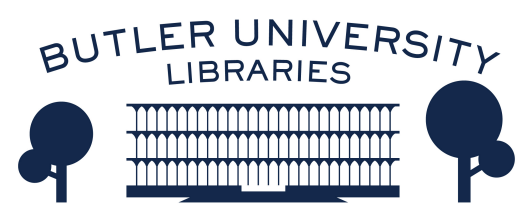

Journal of Hindu-Christian Studies

Volume 21

Article 5

January 2008

\title{
A Retrospective of Hindu-Christian Studies: Establishment of the Journal and Formation of the Society
}

Harold Coward

Follow this and additional works at: https://digitalcommons.butler.edu/jhcs

Part of the Religion Commons

\section{Recommended Citation}

Coward, Harold (2008) "A Retrospective of Hindu-Christian Studies: Establishment of the Journal and Formation of the Society," Journal of Hindu-Christian Studies: Vol. 21, Article 5.

Available at: https://doi.org/10.7825/2164-6279.1404

The Journal of Hindu-Christian Studies is a publication of the Society for Hindu-Christian Studies. The digital version is made available by Digital Commons @ Butler University. For questions about the Journal or the Society, please contact cbauman@butler.edu. For more information about Digital Commons @ Butler University, please contact digitalscholarship@butler.edu. 


\title{
A Retrospective of Hindu-Christian Studies: Establishment of the Journal and Formation of the Society
}

\author{
Harold Coward \\ Professor Emeritus of History \\ and Founding Director of the \\ Centre for Studies in Religion and Society \\ University of Victoria
}

A retrospective look at "How We Do HinduChristian Studies" can be had by going through the issues of our journal from 1988 to the present. In the first issue of the journal the approach was described as follows: "Materials selected for publication will be balanced between historical research and contemporary practice, and, where possible, should employ analytical and theoretical analysis set within the context of our shared human experience." The issue contained two articles illustrating this approach: an overview of Hindu-Christian dialogue in India in the 1970s and 1980s by Anand Amaladass, and an assessment of the various approaches to dialogue in the modern West by Klaus Klostermaier. While Amaladass finds the focus in India in the 1980s to be on church organizations and their theology of dialogue (with some Christians linking dialogue with proselytisation), Klostermaier sees dialogue is the West occurring at the academic level in Religious Studies courses where he feels there is a greater openness and honesty "where formerly dissimulation and hypocrisy were the rule." ${ }^{2}$ In each tradition, says Klostermaier, our study requires scholars who are willing "to fight hard against prejudice and pretense, against petrified tradition and vested religious interest" if the Hindu-Christian dialogue is to be open and honest. $^{3}$
In volume 2, the 1989 issue of the Bulletin, the death of Richard Taylor is noted. A missionary of the United Methodist Church, USA, Dick Taylor served in India for 35 years as Research Secretary for the Christian Institute for the Study of Religion and Society in Delhi and Bangalore. Taylor's books assessed the contributions of early pioneers in inter-faith dialogue from a sociological perspective. $\mathrm{He}$ also wrote on Christian art and the Ashram Movement in India. In volume 2 of the Bulletin, the focus on Hindu-Christian dialogue continues with articles by Anand Amaladass and Klaus Klostermaier. Amaladass draws attention to the encounter between Christian Europe and Hindu India in Wilhelm Halbfas' book India and Europe: An Essay in Understanding. For the European, India fascinates as a pristine guardian of primordial wisdom and offers hidden pieces of one's self-understanding. By contrast, on the side of India there is no such searching toward the West - instead, there is only a stance of selfsatisfaction and a lack of curiosity towards the outside. In India there is traditionally no search for challenges and alternatives from foreign shores. Indeed India discovers the West and Christianity through the process of being discovered by the West - although this insulation was broken through by the nineteenth century Indian Renaissance thinkers who set the

Harold Coward is Professor of History and Founding Director of the Centre for Studies in Religion and Society, University of Victoria. He has authored eighteen books, the most recent of which is The Perfectibility of Human Nature in Eastern and Western Thought (SUNY, 2008). He was the founding Editor of the Journal of Hindu-Christian Studies. 
stage for today's Hindu-Christian dialogue. In her article, Margaret Chatterjee (Director, Indian Institute of Advanced Studies, Shimla) identifies six principles for Hindu-Christian interaction including the felt need of Indian Christians to inculturate their faith in Hindu cultural practice, thus requiring the study of Hinduism in Christian seminaries. Chatterjee also notes that there is a draw for some few Christians to the mystic route (e.g. Advaita Vedanta) of Hinduism. ${ }^{4}$ One such person, Jacques-Albert Cuttat (son of a wealthy Swiss banker, Professor of Philosophy at the Sorbonne, later the Swiss Ambassador to India) was fascinated by the mysticism of Vedanta. The "Cuttat Study Group" which he established during his tenure as the Swiss Ambassador in Delhi focused on the notion of "inner dialogue" which must precede "external dialogue" Cuttat stressed the need to develop methods for an encounter of spiritualities rather than a mere engagement in comparative religion. ${ }^{5}$

The focus on "dialogue" as the key to Hindu-Christian studies continued in the 1990, 1991 and 1992 issues of the journal. Robert Baird examined the relationship between dialogue and academic study, and was complemented by Francis Clooney's analysis of the transformation of the scholar as a factor in Hindu-Christian Studies. ${ }^{6}$ In the same issue Bettina Baumer of the Abhishiktananda Society in Varanasi points out three levels of dialogue: on the lay level between neighbours, at work or in the family; on the academic or intellectual level; and on the bhakti or devotional level like the sharing of festivals, prayers and rituals. ${ }^{7}$ Richard De Smet offers an assessment of "de Nobili as Forerunner of Hindu-Christian Dialogue," and John Carman suggests that Protestant Bible translations in India constitute an unrecognized example of Hindu-Christian dialogue. ${ }^{8}$ Art and architecture are seen as locus for dialogue by Caroline MacKenzie and Jyoti Sahi. ${ }^{9}$ In the 1992 issue the focus on dialogue continues but in an academic comparative voice. Julius Lipner offers a comment on the concept of hindutva in relation to the Christian Roman Catholic ascetic, Brahmabandhab Upadhyay (1861-1907). Ronald Neufeldt looks at the contribution of Max Muller to the comparison of Christianity and "other religions," and Devadatta
Dabholkar sees Gandhi as a living embodiment of Hindu-Christian dialogue. ${ }^{10} \mathrm{~S}$. Gangadaran and Israel Selvanayagam offer a comparison to the communion of Saints from Tamil Saiva and Christian perspectives. ${ }^{11}$ It is worth noting that in the 1992 issue of the journal a balanced engagement of both Hindu and Christian scholars is achieved for the first time.

The comparative approach continued in the 1993 issue of the journal but with a context shift from dialogue to the question of human responsibility for the environment. Articles from Klaus Klostermaier and Roger Hutchinson along with O. P. Dwivedi and Sehdev Kumar once again showed a balance of Christian and Hindu scholars. The passing of Bede Griffiths, a leader in Hindu-Christian dialogue was noted. In the reviews, the publication of Francis Clooney's first venture into comparative theology was examined. In the 1994 issue the focus on HinduChristian dialogue reappears but now in the context of religious pluralism in India, America and Australia with articles by Clooney, Chatterjee, Carman, Ayookuzhiel and Bilimoria. In a viewpoint essay, David Scott (of the United Theological College in Bangalore) examines the relationship between religious fundamentalism and pluralism in India. ${ }^{12}$ Also in 1994, the founding meeting of the Society for HinduChristian Studies was held in conjunction with the American Academy of Religion meetings in Chicago. In relation to the question, "How do we do Hindu-Christian Studies?" the founding of the Society provided a permanent home for the journal and fostered a yearly gathering of scholars in the field - a gathering that has grown from an initial group of twenty to our current sessions of fifty or sixty scholars. The program for the Society's first meeting was a panel review of Diana Eck's Encountering God, with a response from the author.

During the five-year period 1995-2000 we see a shift from the focus on dialogue to a series of thematic studies. In the 1995 and 1996 issues of the journal, the topic of the role and function of scripture takes center stage with a comparative method frequently being adopted. The Hindu approach to scripture is analyzed in articles by Anantanand Rambachan and Bibhuti Yadav with the Christian approach being examined by Michael Deroche and R. S. 
Sugirtharajah. Also in these issues Frances Clooney led a cultural and cross-cultural study of the Hindu mind as found in the work of Professor Dharampal and seen in his book Bharattya Chitta Manas and Kala released in Madras in 1993. Responses to Dharampal's statement of the need to decolonize the Hindu mind are offered by Lance Nelson, Anantanand Rambachan, Nilima Chitgopekar and Anand Amaladass. In Viewpoint essays Murray Rogers reflects on the dawn of human-nature ecology reflections in both Hinduism and Christianity, and Fred Clothey asks to what degree HinduChristian studies goes beyond monologue to become dialogue, and argues for the method of "collaborative research" that may change our personal religious experience. ${ }^{13}$ In the book reviews, two comparative studies are noted: Michael Stoeber's Theo-Monistic Mysticism, reviewed by Anantanand Rambachan; and Monastic Life in the Christian and Hindu Traditions, edited by Austin Creel and Vasudha Narayanan, reviewed by Harold Coward. The 1995 issue also contains a most valuable Index of the first seven volumes of the journal offering a fine snapshot of the methods adopted in Hindu-Christian Studies in articles, viewpoint essays and book reviews. Looking over this index impresses one with the depth of stimulation that both the journal itself, along with the formation of our society, has provided to the development of Hindu-Christian Studies. It is also clear that it is time for an Index of vols. 8-20 to be compiled.

The theme for the 1997 issue of the journal was the relationship between science and religion from the perspective of Hindu-Christian Studies, Klaus Klostermaier introduces the theme by calling it a "'Hindu-Christian-Science Trialogue'...which accepts a plurality of religions and sciences as given and understands their relationship in an ecology of the spirit."14 Varadaraja Raman, a Hindu and a physicist, delineates the lines of demarcation between Vedanta and modern science. Subhash Kak, a Hindu and a computer scientist, reads the Vedas as a code for ancient science - a background for the development of Vedanta as he sees it. Robert Russell sees a positive, creative interaction between science and Christian theology. Gordon Winder, a Christian and a geologist, finds quotes in the Bible that support the ending of any conflict between science and religion. The methodology here is not really comparative but rather an inner attempt of each tradition to relate itself positively to modern science. In the 1998 issue the theme of "The Hindu Diaspora" is studied through a series of historical surveys: in Trinidad (Marion O'Callaghan); in Australia (Purushottema Bilimoria); in North America (Raymond Williams); and in Europe (Martin Baumann). In his Viewpoint essay "On Being a Hindu-Christian," Tinu Ruparell reflects on his experience of diaspora and living as "a HinduChristian." This he understands through the literary method of the application of metaphor "The metaphorical nature of being a HinduChristian," says Ruparell, "means that such a state is highly particular, open-ended, and creative...taking on almost limitless forms." 15 The 1998 issue closed with tributes to two colleagues at their passing: Richard De Smet by Julius Lipner; and M. M. Thomas by S. Wesley Ariarajah. It is also noted that Kenneth Cracknell has compiled a bibliography of "One Hundred Books on Hindu-Christian Dialogue."

"Time in Christian and Hindu Thought" is the theme adopted for analysis in the 1999 issue, and the method is mainly philosophical. Robert Neville and David Hawkin look at "Christianity and Time" while Vasudha Narayanan and Harold Coward examine "Time in Hinduism." In the same issue Francis Clooney offered a Viewpoint essay highlighting discussion on the Society's web-based list of violence in India involving Hindus and Christians connected with conversion. In a two month period over 150 contributions had been made on the HinduChristian Studies List on matters relating to religion and religious conflict in India - often focusing on conversion and proselytization. This online discussion among Society members prompted a panel on "conversion" at the 1999 Annual General Meeting with the method of analysis being mainly historical. In the midst of the continuing online controversy over conversion the 2000 issue of the journal offered a scholarly analysis of Christian misperceptions of Hindus and Hindu misperceptions of Christians. Articles by Thomas Thangaraj on "Mutual Misperception", Brian Pennington on "Rev. William Ward," Ronald Neufeldt on 
"Conversion and the Courts," Deepak Sarma on "Is Jesus a Hindu?" and Tinu Ruparell on "Hindu Occidentalism". offer clear corrections and constructive new approaches to the way Hindus and Christians perceive and misperceive each other. The methods used in these articles are historical and philosophical.

In the 2001 issue the focus on "perceptions" continues in the theme "How My Thinking Has Changed." The method adopted is largely one of introspective analysis. Murray Rogers reflects on a half-century of living Hindu-Christian dialogue and finds that the loss of faith he used to fear from studying and sharing with Hindus has in fact turned into the opposite - a deepening and enrichment. Seshagiri Rao describes how his Hindu thinking has changed as a result of participating in dialogue with Christians, especially through the World Council of Churches. Rao reports that this has led to a deepening of understanding of both traditions. Anantanand Rambachan reflects on how his encounter with Christianity has changed his assessment of the Advaita doctrine of God. Rambachan invokes the Christian concepts of immanent and transcendent to influence his understanding of the Upanisadic concepts of nirguna and saguna to be complementary rather than exclusive and hierarchical - pointing to a creator Brahman that is both immanent and transcendent. William Cenkner, reflecting on his own scholarly experience, argues that dialogical approaches to Hindu-Christian studies have more to offer than dialectical approaches because the latter fail to lead one back to the foundational insight of the tradition whereas the dialogical method often does. In his Viewpoint essay Kenneth Cracknell observes that Martin Buber, Wilfrid Cantwell Smith, and Ninian Smart have each shown ways through the obstacles of "mutual misunderstanding, suspicion and cultural arrogance" which marked what Cracknell calls the old relationship between the Hindu and Christian traditions.

With the 2002, vol. 15 of our journal the editorship shifts from Harold Coward to Bradley Malkovsky, with the theme of "the Conversion Controversy" (the meaning and legitimacy of mission and conversion) being picked up again from our 2000 issue. Two Hindu and two Christian assessments are offered with the methods employed being largely those of theological, historical and textual study. Michael Amaladoss places the controversy within the context of the history of India, and notes that conversions are not just spiritual acts but also events with psychological, social, cultural, economic and political aspects. Conversion, he argues, is a free individual decision and needs to be respected by all. Arti Dhand examines the issue from the context of a close reading of the Mahabharata's attitude to other faiths. She finds that the Mahabharata never advocates violence as a way of dealing with believers of other faiths, rather a broadminded tolerance is advocated. In his article, Judson Trapnell compares two Hindu and two Christian approaches to the issue. On both sides intolerant and more open views are found. For example, Roman Catholic liberation theologians in India advocate not a conversion of people from one religion to the other but a conversion of all both Christian and Hindu - to the Gospel values of dialogue, justice, freedom and community. Anantanand Rambachan, in his analysis, notes that exclusivistic and inclusivistic approaches have long existed among both Hindus and Christians, but what has been characteristic of the Hindu approach to conversion is the idea that there are many ways of being religious. Christian mission in the modern era, by contrast, has often been linked to Western colonialism and arrogance, showing little regard for Indian culture and customs - leading to a widespread Hindu resentment and distrust of Christianity. This stereotyping of Christianity needs to be overcome and Hinduism challenged to recognize why some of its members become disillusioned and turn to the Gospel proclamation of the inclusive love of God, and of human community, dignity and equality.

"Vedanta and Christianity" is the theme of the 2003 issue of the journal with articles by Klostermaier, Rukmani, Ulrich and Rambachan. The impact of Advaita Vedanta on Christianity is examined by two Hindu and two Christian scholars. These essays are mainly historical and theological in their method of study. Klostermaier summarizes the achievements and failings of three twentieth century European Christian sannyasins living in India: Father Jules Monchanin, Dom Henry le Saux, and Dom Bede 
Griffiths. While many Hindus regard such attempts at inculturating Christian monasticism into Hindu garb as illegitimate, Klostermaier finds a real affinity between some Hindu and Christian spiritualities in their common quest to realize the presence of the eternal in this world T. S. Rukmani focuses her analysis on the attempt of Richard De Smet (1916-1997) to interpret Sankara's Advaita Vedanta. Rukmani concludes that De Smet ends up misunderstanding Sankara mainly because of his inadequate understanding of Sanskrit exegetical method and due to a very selective reading of Sankara's texts. Rukmani concludes by noting a necessary opposition between the Christian and Advaita understanding of the Ultimate Christianity's personal creator God, and Advaita's impersonal and non-relational Brahman. Ted Ulrich finds that like De Smet, Henri Le Saux (Swami Abhishiktananda) does not adequately follow the path of scholarly exegesis of Upanisadic texts as laid down by the Advaita tradition. Instead he read the Upanisads repetitively and prayerfully, as prescribed by Ramana Maharshi, side by side with the passages from the Bible. This process led to deepening his understanding of both sacred texts and a transforming encounter with the Divine. In his article Anantanand Rambachan examines the work of the contemporary biblical scholar Marcus Borg in terms of its significance for the Advaita-Christian encounter. Borg proposes as an alternative to Christianity's traditional anthropomorphizing theism, a theology that asserts God as an all-pervasive reality - a view that has similarities to the Advaita teaching of Brahman. In place of the usual Christian categories of sin and guilt, Borg proposes "blindness to the presence of God" which Rambachan sees as akin to the Advaita concept of avidya or ignorance. In Borg's interpretation Rambachan finds that Christian theology has much to gain from Advaita, but he also argues that Advaita could learn from Christianity a heightened sense of the reality of the world and its need for social justice and the alleviation of physical suffering. Also in the 2003 issue is an essay by Rachel Fell McDermott who asks what Christians learn when they study the Bengali devotional traditions and the Hindu goddesses Kali and Durga with their wrathful and compassionate appearances, and their association with the cult of blood sacrifice. McDermott adopts the method of historical survey in her study of Christian attempts to find a rapprochement with this version of Hindu Saktism, noting the absences, peculiarities and challenges of the Christian responses to Kali and Durga. She finds that Christian scholars, whether focusing on theological/philosophical or devotional analysis in their assessment of Hinduism, have avoided engaging with Saktism - mainly because they find the goddess worship they encountered in Bengali Hinduism offputting. McDermott cites Hans Kung's response that Saktism and Tantrism are "extraordinarily alien to Christians" as typical. ${ }^{16}$ In spite of a few attempts at what she calls "theological crossings" (e.g. John Woodroffe, Diana Eck and David Kinsley), McDermott concludes that these efforts are rather minor and need further exploration. She suggests that Christian concepts such as the Holy Spirit, the acceptance of death and of God as intimately merciful may provide "bridges" for the Christian approach to the understanding of Saktism and goddesses such as Kali. The final essay in the 2003 issue is a Viewpoint call by Deepak Sarma for scholars of Hinduism and Christianity to respond to the instances of violence between Christians and Hindus : within India - that scholars should acknowledge their duty as public intellectuals and come down from the ivory tower to engage their voices in interreligious dialogue on the issues of violence and justice taking place on the street. ${ }^{17}$

The 2004 issue marked the change of name from "Bulletin" to "Journal," and a return to the topic featured in the first issue of our journal, namely, "Hindu-Christian Dialogue." However, the 2004 articles signal a new approach with its title "Dialogue: 'On the Ground"" - a focus on the encounter that takes place between Hindus and Christians in India. Rather than studying historical, colonial, missiological or doctrinal dimensions of dialogue (which often leave out the lived experience of people on the ground), this new approach observes the more fluid and spontaneous dialogical models embraced by Hindu and Christian laity in India. At that level the dialogue is more anchored in the grassroots encounter of religious praxis, rather than in 
theological abstractions and conceptual, elitist institutionalized activities. In this lay, on the ground dialogue, what is often revealed are the complex and complicated identities of Hindus and Christians in India. As Brad Malkovsky points out, there is an increasing number of Ph.D. dissertations in this "popular religion" area of study. These studies "should add breadth and depth to traditional notions of what constitutes 'Hinduism,' 'Indian Christianity,' and the Hindu-Christian encounter." 18 The articles are by B. K. Bajaj and M. D. Srinivas (dialogue around the issue of idol-worship, cowprotection, and conversion), Francis Clooney (a critique of a statistical analysis of India's shifting demographics), Vasudha Narayanan (description of Hindu and Christian religious practice in two South Indian Christian churches where worshippers of both religions come together and all experience "spiritual power"), and Selva Raj (a study of shared religious space and practice at the shrine of St. Anthony, Uvari, Tamilnadu). The last two articles, especially, show an "on the ground dialogue" that involves communion across religious boundaries and the blurring of identities between Hindu and Christian. Other very useful articles in the 2004 issue include Matthew Smaltz's bibliographic essay on Hindu and Christian Dalit Religiosity, and Thomas Thangaraj's six year experience in teaching a course titled "A Christian Encounter with Hinduism" at Emory University in Atlanta, which involves the advanced Christian theological students and their experiences of visiting a Hindu temple and of meeting with Hindu visitors to the class - both being situations of creative on the ground dialogue rather than an encounter between "Christianity" and "Hinduism" as religions. ${ }^{19}$ The 2004 issue also contained tributes to two recently deceased members of the Society: William Cenkner (1925-2003) and Judson Trapnell (1954-2003).

"Can women be priests?" is the topic for the 2005 issue of the journal. The four essays offered take up the question ethically, theologically and historically with special attention to contemporary debates and innovations. Susan Ross examines the arguments advanced for and against women's ordination to the priesthood, especially in the Roman Catholic church. Maura Ryan offers an ethical analysis using feminist theory on the ordination of women to the Roman Catholic priesthood, and argues that such ordination would be an expression of social and humanitarian justice. Concerning the Hindu traditions, Laurie Patton offers evidence from antiquity that women recited mantras in certain sacrifices and rituals as well as presiding over marriage rites. According to Mimamsa women enjoyed ritual authority by virtue of being married. Vasudha Narayanan explores the many meanings and functions associated with Hindu priesthood in both the home and the temple. She finds that today women have an increasing access to priestly duties such as reciting and teaching scripture, performing death rites, conducting Vedic sacrifices, officiating over temple rituals, and wearing the sacred thread. She suggests that it is the very diversity and lack of centralized authority in Hindu traditions that enables such spontaneous changes to occur. In the same issue Michael McLaughlin offers an essay comparing Mimamsa ritual and the Eucharist and Tinu Ruparell compares Leibniz with Ramanuja, - with both essays using Clooney's comparative theology method.

The 2006 issue examines the topic of book banning and religious censorship in recent years, with essays on the 2004 Bhandarkar Oriental Research Institute library being ransacked by the Sambhagi Brigade in response to the publication of James Laine's biographical study, Shivaji: Hindu King in Islamic India, a book that was subsequently censored throughout India. He suggested that the controversy seems to be caused by Hindu objections to Western "outsider" scholarship redefining a Hindu hero an issue which Jeffrey Kirpal also examines in his essay. Gerald Larson enlarges the question of censorship in India by noting that since Independence the major book banning controversies have involved Hindu-Muslim interactions and Neo-Hindu revisions of the history and meaning of Hinduism. Daniel Sheridan's essay provides a historical overview of the banning or prohibiting of books in the Catholic Church, starting with the formation of the biblical canon and the condemnation of the works of Origen, John Wyclif, John Hus, Martin Luther, John Calvin and the formation of the Index of Prohibited Books which remained in 
force from 1557 to 1966 . In her Viewpoint essay Corinne Dempsey offers an ethnographic reflection on her "out of place" studies of popular Christian practice in predominantly Hindu South India, and a Hindu temple within the Christian context of rural upstate New York. In the book reviews, the resurrection of an important research tool, "Genealogy of the South Indian Deities" via English translation and textual analysis is discussed by Francis Clooney as a scholarly contribution that informs us about $18^{\text {th }}$ century India, and places the study of Protestant missionary scholarship in India on a solid textual basis. This comment leads me to observe that the rich offering of book reviews throughout all twenty issues of the journal are a most important tool for us in our doing of Hindu-Christian studies. Re-reading them gives one a fine sense of the enlarging and deepening of Hindu-Christian scholarship between 1988 and the present.

In the 2007 issue of the Journal (about to appear), the theme is "Love of God" and the main method adopted seems to be that of comparative theology. The Viewpoint essay by Raimundo Panikkar argues for a dialogical approach to Hindu-Christian studies that goes beyond doctrines and theories and situates itself in the living experiences of people in their languages, cultures and rituals. Panikkar brings this "Retrospective" full circle back to the 1988 "Foreword" he wrote to the book HinduChristian Dialogue where he describes how throughout his life he has shared in the languages, cultures, scriptures, and rituals of both the Hindu and Christian traditions without absolutizing either. It is in this way that he has lived a life of dialogue - a dialogue among cultures and religions upon which, as he puts it, the peace of our planet depends. ${ }^{20}$ Panikkar's two reflections are fitting "bookends" to the twenty years of Hindu-Christian Studies initiated by the 1987 book project in Calgary, the 1988 vol. 1 of our Journal, the 1994 founding of our Soceity and the 2007 methods reflection on "How We Do Hindu-Christian Studies." I feel sure Panikkar will have appreciated the vol. 17 approached of "Dialogue - on the Ground," for that has been his way of life.

\section{Conclusion}

Reading through the twenty issues of the Journal (1988-2007) I found myself impressed with the great variety of methods and diversity of subject matter. The methods of study employed in the one hundred plus articles published in our Journal include: historical, phenomenological, comparative (using scripture, theology, worship and ritual as content), philosophical, ethnographical, ethical, feminist, and even statistical. The topics covered include: dialogue (perhaps the most dominant topic especially from 1988-92), ecology/environment, religious pluralism, scripture, religion and science, the Hindu diaspora, time in Hindu and Christian thought, mutual misperceptions, conversion (a recurring theme), Vedanta and Christianity, women and the priesthood, and censorship (book-burning). The Viewpoint essays have added a valuable additional scholarly dimension to our studies, as have the over one-hundred and fifty reviews of the key books published in our field. Indeed, re-reading many of these reviews, which in our Journal tend to be longer and thus be able to engage issues more deeply, left me convinced that the reviews themselves play an important role in the way we do Hindu-Christian Studies.

The tools identified for study included a Journal Index covering the 1988-95 issues (a follow-up index to bring us to the present is badly needed), the Bibliography of 100 books put together by Kenneth Cracknell in 1997, the online discussions list maintained for many years by Lance Nelson, and the work of our longtime co-editor Anand Amaladass to keep us engaged with scholars and scholarship in India.

All in all, this Retrospective study of how we have done Hindu-Christian Studies, from 1987 to the present, through our Journal and Society, convinces me that a firm foundation has been laid for future scholarship in this field.

\footnotetext{
Notes

${ }^{1}$ Hindu-Christian Studies Bulletin, vol. 1, 1988, p. 1.

${ }^{2}$ Ibid., p. 9.

${ }^{3}$ Ibid.

${ }^{4}$ Margaret Chatterjee, "The Prospect for HinduChristian Interaction," Hindu-Christian Studies Bulletin, vol. 2, 1989, p. 2.
} 
5 Klaus Klostermaier, "Jacque-Albert Cuttat: a Pioneer of Hindu-Christian Dialogue," HinduChristian Studies Bulletin, vol. 2, 1989, p. 4

6 See Robert Baird, "Academic Study and the Phinomena of Dialogue," and Francis Clooney, "The Transformation of the Scholar as a Factor in HinduChristian Studies," in vol. 3, 1990, pp. 7-11 and pp. 1-6, Hindu-Christian Studies Bulletin.

7 Bettina Baumer, "Levels of Dialogue," HinduChristian Studies Bulletin, vol. 3, 1990, pp. 33-34.

${ }^{8}$ See Richard de Smet, "R. de Nobili as Forerunner of Hindu-Christian Dialogue," and John Carman, "Protestant Bible Translations in India: An Unrecognized Dialogue?" in vol. 4, 1991, HinduChristian Studies Bulletin, pp. 1-9 and pp. 11-21.

${ }^{9}$ Tbid., pp. 31-38.

${ }^{10}$ See Julius Lipner, "On 'Hindutva' and a 'HinduCatholic' with a Moral for our Times," Ronald Neufeldt, "Christianity and "Other Religions: Contributions from the Work of F. Max Muller," and Devadatta Dabholkar, "Mahatma Gandhi: A Living Embodiment of Hindu-Christian Dialogue," in vol. 5, 1992, see pp. 1-8, 9-12 and pp. 23-28.

${ }^{11}$ Ibid., pp. 13-19.

12 David Scott, "Religious Fundamentalism and Pluralism in India," Hindu-Christian Studies Bulletin, vol. 7, 1994, pp. 45-47.

13 Fred W. Clothey, "Hindu-Christian 'Studies': Some Confessions from the Boundaries," HinduChristian Studies Bulletin, vol. 9, 1996, pp. 42-45.

${ }^{14}$ Klaus Klostermaier, "The Hindu-Christian-Science Trialogue," Hindu-Christian Studies Bulletin, vol. 10, 1997, pp. 5-11.

15 Tinu Ruparell, "On Being Hindu-Christian," Hindu-Christian Studies Bulletin, vol. 11, 1998, pp. 45-48. See p. 47.

${ }^{16}$ Rachel Fell McDermott, "Meeting 'the Mother Who Takes Across': Christian Encounters with Fierce Goddesses of Hinduism," Hindu-Christian Studies Bulletin, vol. 16, 2003, pp. 48-57. See p. 51.

17 Deepak Sarma, "Fostering Dialogue and Interreligious Conversation," Hindu-Christian Studies Bulletin, vol. 16, 2003, p. 56.

18 Bradley Malkovsky, "Editor's Introduction," Journal of Hindu-Christian Studies, vol. 17, 2004, p. 1.

19 M. Thomas Thangaraj, "Pastors, Pujaris, and Swamis: Hindu-Christian Encounter in a Classroom," Journal of Hindu-Christian Studies, vol. 17, 2004, pp. 66-68.

${ }^{20}$ Raimundo Panikkar, "The Methodic of HinduChristian Studies," Journal of Hindu-Christian Studies, vol. 20, 2007. 